\title{
PRIVACY IN WELFARE: PUBLIC ASSISTANCE AND JUVENILE JUSTICE
}

\author{
Joel F. Handler* and Margaret K. Rosenheim $†$
}

At the risk of stating the obvious, we may observe at the outset that the sensitive areas of privacy appear to have different boundaries depending upon one's status in society. Poor and otherwise dependent persons, however defined at a given moment, are likely to be less secure in enjoyment of "private personality" than persons in other social classes. Persons whose dependency arises out of financial necessity lack resources to interpose the customary screens around their private activities and to keep themselves shielded from the prying eyes of others. Yet the lesser protection of privacy does not stem merely from lack of the things that money will buy. It also results from a peculiar vulnerability of the needy and dependent to official or quasi-official inquiry and surveillance. The institution of protective governmental programs is frequently accompanied by an authority to investigate and control the clientele's behavior which is inapplicable to other groups. Thus, to the familiar competing interests that affect the scope of the privacy individuals enjoy must be added society's interest in ascertaining that the goals of protection and support, incorporated in an ever-widening spectrum of governmental welfare programs, are being carried forward. How this task is currently accomplished and what guiding principles of accommodation of private and social values might be stated are the two topics we have set out to discuss.

In one sense, of course, the questions to be considered are not new. For as long as government has undertaken to supply food, shelter, medical care, or guidance and control to the incompetent, to name obvious functions, there have existed the issues with which we shall be dealing. Unlike the newer conflict between the demands of science and those of personality, ${ }^{1}$ the issues arising out of welfare functions are not so much the product of modern technology as of an ancient tension between charitable instincts and an interest in public efficiency. ${ }^{2}$ The latter concern for proper limitations on public support, we may note, is often affected by discernible resentment of dependency on the part of those who are tapped to offer the support and by the view that society should tell dependents how to live and behave. Notwithstanding the venerability of these basic issues, it can be argued that the very recognition of

- A.B. I954, Princeton University; IL.B. 1957, Harvard University. Professor of Law, University of Wisconsin.

†J.D. 1949, University of Chicago. Professor, School of Social Service Administration, University of Chicago. Editor, Justice for the Child: The Juvenile Court in Transition (I962).

${ }^{2}$ See, e.g., Ruebhausen \& Brim, Privacy and Behavioral Research, 65 Colum. L. Rev. II84 (I965).

See generally Eveline M. Burns, Social Security and Public Policy (1956); Hilary M. Leyendecker, Problems and Policy in Public Assistance (I955); Karl de Schweinitz, England's Road to Soctal Security (1943). 
newly-emerging conflicts between the public interest and the privacy claims of individuals lends a special pertinence to examining the measures of inquiry, observation, and control imposed on dependent persons. Such an undertaking can serve at least two ends: it may stimulate a re-examination of practices whose antiquity does not necessarily confer legitimacy, and it may suggest analogies of use to other fields where the conflicting values at stake are unusually difficult to balance.

\section{The Scope of Governmental Welfare Activities}

In modern terms, "welfare" programs signify a range of organized schemes for the provision of income, work, counseling, and other specialized aid (such as medical care), as well as the state's assumption of superparental responsibilities for children and the mentally incompetent. We may include in addition the supplying of housing and education. ${ }^{3}$ Excluded in the common use of "welfare" is one protective function par excellence-the preservation of law and order. Yet, while law enforcement and the operation of correctional facilities will seldom be confused with welfare activities, there is a class for whom welfare and law enforcement merge-minors in the juvenile justice system. ${ }^{4}$ And in connection with adults the distinctions are sometimes fuzzy. ${ }^{5}$ Some common threads unite these disparate elements. One is relief of suffering; another, the prevention of injury, to individuals as a matter of humanity or to the state as an assumed consequence of letting unguided or destructive behavior continue unchecked; still another, the desire to rehabilitate, to prepare people to face their life situations.

One scarcely needs to be reminded where the emphasis is presently placed in disbursing governmental welfare, as defined. Provision of income is the paramount function. Specialized health activities and education are not too far behind. But even lesser functions, as measured by cost, are consequential in terms of numbers of persons affected, expenditures involved, and social attitudes shaped by their very existence. ${ }^{b}$

A wide variety of governmental undertakings, then, may be characterized "welfare." Sometimes particular programs are focused on a sharply defined population and are constructed to meet a single objective. In many others, however, the objectives are multiple, not necessarily consistent with one another, and occasionally hard to identify. In the latter instances it should not surprise us if the target populations are less well-defined and the methods of administration more varied. And to the extent that specific welfare programs depend on discretionary administration,

\footnotetext{
${ }^{3}$ See Merriam, Social Welfare Expenditures, 1964-65, Social Security Bull., Oct. 1965, pp. 3-5.

* See Francis A. Allen, The Borderrand of Criminal Justice 43-49 (1964); Tappan, Jutridical and Administrative Approaches to Children with Problems, in JUstICE FOR THE CHID 144 (Rosenheim ed. 1962).

${ }^{5}$ See, e.g., ALtex, op. cit. supra note 4, at 5-7; Rosenheim, Vagrancy Concepts in Welfare Law, 54 CAIIF. L. REV. 5II (Ig66).

- Merriam, supra note 3, at 4; cf. Titmuss, The Role of Redistribution in Social Policy, Social Security Bull., June 1965 , p. $x_{4}$.
} 
either in initial determination of the population to be served or in the types of conditions imposed in the course of service, we can expect to uncover a substantial number of practices which it is useful to discuss in the context of privacy.

Perhaps the point will be sharpened by illustration. The comparison is commonly drawn between social insurance and public assistance as alternative ways of providing income maintenance. Both approaches basically seek the same goal-elimination of destitution through regular governmental income payments. Social insurance, in this country a twentieth-century innovation, is associated with a detailed statutory definition of eligibility, a statutorily prescribed benefit schedule, and, often, a contributory scheme of financing. Public assistance, by contrast, is a modern-dress version of poor relief. As such, its disbursement depends on administrative determination of need within broad guides set forth by statute, the authorization of payments designed to meet specific individual needs as they arise, and support from sources of general taxation-federal, state, and local. The crucial difference between the two approaches centers on the concept of need. In the case of social insurance, need is presumed to arise; ${ }^{7}$ the payments made are presumed to be sufficient to guard against the destitution of persons not subject to extraordinary hazards. ${ }^{8}$ It is precisely the unusual circumstance to which public assistance is oriented in its proclaimed concern to relieve individual need. ${ }^{9}$ Simply because no legislative determination of social policy can cover all contingencies, the design and administration of public assistance necessarily concentrate on the unique personal circumstances of the recipients. To fulfill the commendable goal of relief of a person's suffering requires an intimate knowledge of his appetites and needs. The very approach of public assistance demands varying degrees of exposure of the applicants' lives and affairs to those who administer it. Needs, exposure, and regulation supply the basis of governmental intervention and generate the privacy questions.

\section{II}

\section{Some Examples of Privacy Issues in Public Așsistance}

We have already alluded to the fundamental factor that gives rise to issues of private personality in the field of public assistance, namely, the pervasive requirement of establishing need. The requirement applies at the point of initial request; and it is continuing, for as an individual's or family's situation changes, the responsibility of government is altered. Absent need in its technical sense, the potential or actual

\footnotetext{
${ }^{7}$ Everine M. Burns, The American Social Security System 35-36 (1949). For a useful discussion of the two approaches, see tenBroek \& Wilson, Public Assistance and Social Insurance-A Normative Evaluation, I U.C.L.A.L. REv. 237 (1954).

${ }^{8}$ It was the clear intention of the framers of the Social Security Act to establish social insurance as the first line of defense against want, relegating public assistance to a minor role. Id. at 238 . See generally Burns, Social Security in Evolution: Toward What?, 39 Soc. Service Rev. I29 (1965).

- The circumstances may be unusual in the sense that the risk to maintenance of income does not readily lend itself to coverage by social insurance (e.g., "the risk of family break-up attributable to causes other than the death of the breadwinner") or involves unpredictable costs (e.g., medical care). Id. at 135 .
} 
recipient is disqualified from receiving support. The critical question, therefore, concerns how need is established and re-established. What are the customary rules and what evidence have we as to their administration?

The primary tool for need determination is the so-called means test. Long excoriated for its humiliating dehumanizing aspects, it has been a key feature of poor relief and public assistance in the United States. ${ }^{10}$ The modern administration of the means test takes different forms, as best we can determine, depending upon what state and what program we are talking about or upon who is charged with applying the test. ${ }^{11}$ A few generalizations can be hazarded just the same.

As a rule, the poorer states are under greater pressure to administer public aid with stringency. In all the states, rich and poor, a variety of strategies may be employed to meet politically-demanded results. ${ }^{12}$ The scope of coverage under a welfare program obviously sets the potential limits of charges on public funds. By restricting the definition of classes of eligible persons a state may control the total caseload of persons reliant on governmental support under that particular program. ${ }^{13}$ Thus, by statute it may define mothers eligible for Aid to Families with Dependent Children (AFDC) to exclude those with a man in the house, or it may accomplish this or similar ends through administrative regulation. ${ }^{14}$ Another strategy to control expenditures is to adopt a "paper" standard of living to set the theoretical limits of need but to make payment of grants at less than one hundred per cent of the state's own standards. ${ }^{15}$ Obviously, grants based on eighty per cent of need will encompass more people than will full grants, given the same size appropriation.

A third prominent strategy is the use of stringent standards of means-test administration. ${ }^{16}$ This entails an exhaustive check of income and resources available to the claimant, and may lead the welfare administration to count on resources that are more theoretical than real; it also includes, by the nature of public assistance, continu-

\footnotetext{
${ }^{10}$ Eveline M Burns, Social Security and Public Policy 64-65 (1956); Mandelker, The Need Test in General Assistance, $4 \mathrm{I}$ VA. L. REv. 893 (1955); Note, Abolish the Means Test for Old Age Assistance, I7 SOC. SERv. REv. 213 (I943).

${ }^{11}$ See Bentrup, The Profession and the Means Test, Social Work, April 1964, p. I5.

${ }^{12}$ Compare Winifred Bell, Aid to Dependent Children (I965).

${ }^{13}$ A good example of this strategy is found in the segment of Aid to Families of Dependent Children providing especially for unemployed parents (AFDC-UP). Only 18 states have adopted AFDC-UP, with definitions of unemployment which vary considerably in liberality. The jurisdictions without AFDC-UP may provide support to unemployed parents under general assistance to the extent that able-bodied and unemployed men are not ineligible thereunder for aid. Even if the parents are eligible, general assistance grants are less satisfactory in terms of amount and eligibility conditions than those provided under the federally-aided categories. See U.S. Dep't of Health, Education and Welpare, Puduic Assistance Rep't No. 39, Characteristics of General Assistance passim (1959).

${ }^{14}$ See, e.g., Center on Social Welfare Policy and Law, Columbia University School of Social, Work, Memorandum on Social Welfare Law "Testing" Function 3-5 (1965); National Ass'N of Social Workers, Metropolitan Washington Chapter, The Public Welfare Crisis in the Nation's Capital 40-43 (1963).

${ }^{15}$ Report of the Advisory Council on Public Assistance, S. Doc. No. 93, App. B, 86th Cong., 2d Scss. 54-75 (1960). See also id. at 75-87.

${ }^{16}$ See Eveline M. Burns, Social Security and Public Policy 65-66 (1956); Mandelker, stipra note Io.
} 
ing scrutiny of the client's private affairs so as to detect any change in needs or available sources of income. A further aspect of means-test administration entails the implementation of policies promoting rehabilitation of the chronically dependent. Restoration to self-support, a goal appropriate only to those physically and mentally capable of work, is an unexceptionable objective of public policy. Execution of the rules designed to bring about restoration to productivity, however, involves the risk that the possibility of work, administratively determined, may be transformed into a resource disqualifying the recipient from future support. ${ }^{17}$ Whatever policy arguments are brought to bear for and against self-support and self-betterment tests as an intrinsic part of public assistance policy, the over-all point to be noted here is simply that the concept of individual need demands a case-by-case decision on applicability of these tests to particular recipients.

Choice of political strategy is dependent on many factors. Cost-reducing techniques may be employed in all income-support programs or in none. Furthermore, the legislative and administrative base of programs may affect their impact. Notable differences exist, for instance, between the general assistance form of public assistance and the Social Security categorical aids. The two forms are distinguished by the standard of relief afforded, conditions of eligibility as to residence, responsibility of relatives and "disregards," geographical coverage, and administrative procedure. Almost universally, the categorical programs provide a more inclusive and dignified form of assistance. ${ }^{18}$ Any privacy issues, therefore, that are identified in the federal grant-in-aid categories may be assumed to exist in general assistance administration as well. The difficulties of documenting these issues, however, gives us license to extract illustrations from any of the public assistance programs, federal-state or state and local.

\section{A. The Means Test and Its Implementation}

What must an applicant for public assistance do to satisfy the conditions of eligibility? He must satisfy the welfare authority that his personal and financial status conforms to elaborate official regulations for establishing eligibility. And he must submit to verification of the facts he alleges. By and large, the initial application for assistance, which is predicated on a supposed gap between income and resources, on the one hand, and the needs of the claimant and his dependents, on the other, suffices as a basis for payment of a grant only at a time of pressing emergency.

Various methods of establishing eligibility are used. Residence is established by inquiry of neighbors and merchants; rent is verified by receipt or inquiry of the landlord; utilities, in the same manner unless, as in some areas, a special billing procedure is used which immediately identifies the customers so listed as public aid recipients. Family relationships are verified, when possible, by checks of official records. The possibilities of securing support from family members legally obligated to contribute

\footnotetext{
${ }^{17}$ Cf. NATIONAI Ass'N of SOCIAL WORKERs, op. cit. supra note 14, at 32-35.

${ }^{18}$ See Eveline M. Burns, The Amenican Social Securuty System 39-40 (1949).
} 
to the maintenance of public charges must, according to most state laws, be exhausted..$^{19}$

Furthermore, by the nature of public assistance, the task of determining eligibility is never-ending. Unlike the duty to pay income taxes, which calls for calculating taxable income accumulated over a prescribed period of time, the obligation of the recipient to report changes in status that alter his needs or his income or resources is continuing. For administrative purposes, enforcement of this obligation is discharged through periodic checks by welfare authorities, ${ }^{20}$ but the recipient carries the burden of reporting when his circumstances change, else he is liable to penalties including prosecution for fraud, permanent or temporary termination of his grant, or withholding from future grants the excess deemed to have been paid out in the past. ${ }^{21}$ Having satisfied the authority of his initial eligibility the client must regularly submit to a truncated version of the same process. Furthermore, because of the requirement to report changed circumstances he can be requested to furnish explanations of inconsistencies in his own statements or of the allegations of third parties that bear upon his eligibility. "Failure to comply" suffices to close a case, ${ }^{22}$ and this general term presumably comprehends insufficient explanation of eligibility factors related to income as well as as unwillingness to accept a work referral ${ }^{23}$ or other manifestations of intractable behavior that bar public assistance. ${ }^{24}$

Emphasis on eligibility determination, as a strategy for controlling caseloads and hence public expense, has produced bizarre rules and practices. The most notable is the well-publicized "midnight raid" or "early morning visit," a clear example of governmental intrusion into private life. Special investigators are commonly employed to go without prior notification to the homes of public aid recipients to determine whether conditions of eligibility are being violated. The existence of unstated resources may be substantiated by such procedures. Characteristically, the agency selects for investigation AFDC clients whose eligibility turns on absence of the male parent. The object of the raid is to discover a "man in the house" or "substitute

\footnotetext{
${ }^{10}$ LEYENDECKER, op. cit. supra note 2, at 216; Burns, What's Wrong With Public Welfare?, 36 Soc. SERv. REv. III (I962). See generally LEYENDECKER, op. cit. supra note 2, at 215-35. It should be noted that relatives' responsibility provisions extend the means test to relatives of the applicant, thus creating privacy issues for relatives as well as recipients.

${ }^{\circ}$ U.S. Dep't of Health, Education and Welfare, Handbook of Public Assistance AdministraTHON pt. IV, $\$ 2230$ [hereinafter cited as HANDBoor]. States are required to redetermine eligibility at least every three months in AFDC-UP, every six months in other AFDC cases, and every twelve months in other programs.

${ }^{21}$ Center on Social Werfare Policy and LAw, op. cit. supra note 14, at 18-19; statutes and cases cited in Reich, Midnight Welfare Searches and the Social Security Act, 72 YALE L.J. 1347, 1351-53 $(1963)$.

${ }^{22}$ See Buread of Fammy Service Div., U.S. Dep't of Health, Education and Welfare, Reasons for Opening and Closing Public Assistance Cases, July-Dec. 1964 (1965).

${ }^{33}$ Most states require acceptance of work referrals as a condition of eligibility for "emplayable" persons. See, e.g., IzI. REv. STAT. ch. 23, §605.3 (I965) (applicable to AFDC).

25 For example, failure to cooperate with law enforcement agencies in locating absent parents for enforcement of support obligations. See SweEt, The ROLE of the State SOcial Wel.fare Board in the Administration of the ANC Program in California 49-62 (Report to Fact-Finding Committce on Labor and Welfare, California Senate, r96r).
} 
parent," whose presence, depending on the jurisdiction, either precludes giving assistance altogether or gives rise to an inference of support, ${ }^{25}$ which, of course, the public assistance agency is obligated to investigate and to take into account in determining the unmet budgetary need. Occasionally, the caseworkers assigned to welfare recipients are asked to undertake this kind of investigation instead of a special unit. Whatever machinery is employed the common element in these investigative practices is surprise. $^{2 B}$ Whether the raids are timed for midnight, or dawn, they are intended to take the recipient unaware at a time of day when it is most likely that "true" family living patterns will be uncovered.

The analogy between this practice and prohibited practices in the criminal law is easy to see. In an extended analysis by Reich, arguments have been made favoring application of constitutional search and seizure doctrines to restrict midnight raid practices. ${ }^{27}$ Under his analysis, evidence that is garnered in the raids would be inadmissible in administrative hearings on suspension or denials of grants, but such an after-the-fact remedy, he concludes, is insufficient, for it fails to bar the practice of investigation. He would induce the Secretary of Health, Education and Welfare to rule out of conformity with federal law, state public assistance plans that countenance illegal practices. ${ }^{28}$ It now appears his arguments, and the chorus of voices approving them, have produced results. Practices in some localities have been revised already; federal "state-plan" requirements mandate investigatory techniques that meet standards of individual dignity and legality. ${ }^{29}$

The case against this particular form of government intrusion into private life is compelling. Yet the control of illegal practices is apt to be as frustrating here as it appears to be in criminal law..$^{30}$ That is to say, the pressure to sustain a productive type of investigatory technique is persistent. Elimination of these admittedly reprehensible midnight raid practices would seem to require adoption of reasonably effective replacements. If we grant that society is willing to pay a certain price in efficiency for investigations that conform to standards of fairness, and thereby preserve other overriding values, we still must ask what substitutes are open that accommodate both the values of individual dignity and the effective administration of popularlydevised welfare programs.

On the surface, it appears that the privacy of persons subjected to a means test is significantly curtailed as compared to other recipients of governmental largess and, further, that the programs that employ the test today are those providing income

\footnotetext{
${ }^{25}$ BeLI, op. cit. supra note 12, at 76-92; CeNTER on Social Welfare Policy and LaW, op. cit. supra note $\mathrm{r}_{4}$, at 3-4; Sparer, Social Welfare Law Testing, Prac. Law., April 1966, pp. 13, 15-18.

${ }^{30}$ BeLI, op. cit. supra note I2, at 88 .

${ }^{97}$ Reich, supra note 2I, at $1347-55$.

${ }^{28}$ Id. at $1347-55,135^{8}-59$. See also Center on SOCIal Welfare Policy and Law, op. cit. supra note 14 , at 20 .

${ }^{20}$ HANDBOOK pt. IV, $\$ \S 2220$ (I), 2230(I), effective July I, 1967.

${ }^{\text {ao }}$ See Handler, Controlling Official Behavior in Welfare Administration, 54 Caurf. L. Rev. 479 (I966); cf. Wayne R. LaFave, Arrest: The Decision to Take a Suspect into Custody (1965).
} 
maintenance to a group of disfavored persons. This in turn affects administration. The argument is a familiar one-that the commonly employed legal and administrative principles of investigation and control are inherently discriminatory and hence improper, possibly on constitutional grounds. ${ }^{31}$ But how does means-test administration compare with other forms of public administration more widely applied?

Cursory examination of the income tax, which we have chosen for its magnetic attachment to the negative income tax proposals, ${ }^{32}$ indicates that all persons in the United States are subject to a considerable amount of governmental investigation into their private affairs vis-à-vis the taxpaying obligation. Those subject to tax must reveal all income that is subject to tax, and all expenses that they wish to offset. They must be prepared to produce detailed records to substantiate their claims. The penalties for failure to report and for omissions may be high. The income tax is indeed a kind of means test in the sense that its applicability and rates discriminate among the various levels of net income, exacting proportionately more from persons with more to report. Yet for all its imperfections the income tax has not been widely attacked as an intrusion into private affairs.

The differences, of course, are important. The assistance-type means test goes further in its demands of personal revelation. It sweeps into determination of need all aspects of income and resources, whereas the taxable base for the income tax may be shaped in part with an eye to administrative cost and to personal dignity. It is a continuing and not an annual or quarterly affair. And its mechanics are more objectionable in personal terms. To take one's word at face value, which is common practice in income-tax administration, is the exception in determining need for assistance purposes. The scale of tax, unlike the scale of payments to recipients, is set by statute applicable nationwide. No one falls into a one hundred per cent bracket, the fate of recipients who earn or receive income since it is fully deducted from their needs..$^{33}$ And so on.

The important point to note, however, is that a test of relative wealth or ability to pay is not confined to public assistance although the offensive form that it takes there is probably unique. The question then remaining is whether this special variety-the means test-is reasonable. Is there any explanation beyond historical accident to support it? At the heart of the matter lies the nature of the social

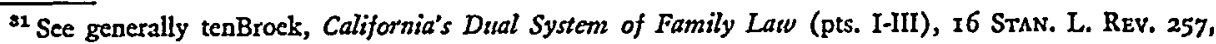
900 (1964); I7 Stan. L. REv. 614 (1965).

${ }^{32}$ Milton Friedman, Capitalisa and Freedom i6r-76 (1962); Schwartz, $A$ Way to End the Means Test, Social Work, July 1964, p. 3, in Poverty in AMERics 48r (Ferman ed. 1965).

${ }^{\text {ss }} \mathrm{It}$ is ironic that whereas carnings may be deducted in toto from the grant, many states do not pay grants that meet in full their own standards of need. See text accompanying note 15 supra. Recent amendments to the public assistance titles have liberalized the income "disregards" permitted under state plans. See, e.g., Public Welfare Amendments of 1962, $\S$ I06(b), 76 Stat. I88 (I962), as amended, Social Security Amendments of 1965,79 Stat. 423, 42 U.S.C.A. \$602(a)(7) (Supp. 1965). With the exception of the Aid to the Blind program and payments made under titles I and II of the Economic Opportunity Act to public assistance recipients or their families, the exemption of earnings and other income is optional to the states. Relatively few have fully availed themselves of the latitude permitted under federal law.
} 
responsibility that governmental agencies are called on to discharge. In a workoriented society the objective of income maintenance, broadly speaking, is to support those who cannot work, for personal or socially desirable reasons, and those who can work but cannot find a job. The governmental obligation begins and ends with those somehow prevented from working or unable to maintain minimum living standards though employed. The principle is clear, but its application is troublesome, as numerous commentators have remarked. If the principle is justifiable as social policy, then it follows that a test of need can be defended as a method of implementing it.

Criticism of the means test in fact hits at punitive and petty policies. It seems to be leaving its mark, as evidenced by recent administrative and statutory changes. The step toward simplified budgeting methods and use of affidavits to replace the detailed investigation and verification of need is one significant sign. ${ }^{34}$ Increasing exemptions of income and resources permitted under federal law is another, ${ }^{35}$ and the publicity attendant on the various guaranteed annual income proposals ${ }^{36}$ is a third indication of dissatisfaction with present income maintenance schemes, including public assistance. Clearly the field is ripe for experimentation.

Nevertheless, the urgency of changing means-test administration ought not to be confused with the "reasonableness" of a means test per se. Discriminations based on income are not only reasonable, they are essential. ${ }^{37}$ No one has yet proposed a blanket measure of need that will wholly eliminate investigation into individual circumstances. Neither family allowances, negative income tax plans, nor expanded forms of social insurance will protect all persons from experiencing suffering in the exceptional cases that are bound to arise. Some additional provision for the unique and unexpected will be required. The popular alternatives to public assistance laws and procedures will not eliminate extended investigation in all cases. They are likely, however, to produce two desirable effects: further shrinkage of the residual needy population to eliminate all but truly exceptional cases, and altered methods of administration. The former requires and is well-suited to legislative action, while the latter calls primarily for changes within the welfare bureaucracy itself, changes to which statutory directives and case adjudication make a limited, albeit occasionally vital, contribution.

\footnotetext{
${ }^{34}$ See, for example, New York City's well-publicized step to accept applications for assistance based on affidavits, commented on favorably in N.Y. Times, March 22, 1966, p. 40, col. I. Effective July I, 1967, federal policy requires states to rely on the categorical assistance client as primary source of information limiting verification of conditions of eligibility to "what is reasonably necessary to assure that expenditures under the program will be legal." Handiook pt. IV, \$2220(5). And see White, Simplified Methods for Determining Needs (Bureau of Family Service Div., U.S. Dep't of Fealth, Education and Welfare, $1964)$.

${ }^{35} 79$ Stat. 418 (1965), 42 U.S.C.A. $\$ 302$ (a) (10)(A) (Supp. 1965); 79 Stat. 423 (1965), 42 U.S.C.A. $\$ 602$ (Supp. 1965); 77 Stat. 51 (1963), 42 U.S.C. §1102 (1964).

${ }^{30}$ See, e.g., Economic Report of the President r I 4-I5 (1966); I National Comm'n on Technology, Automation, and Economic Progress, Report, Technology and the American Economy 39-4I (ig66).

${ }^{37}$ For extended consideration of means-test-type issues, among others, arising under negative income tax proposals, see Klein, Some Basic Problems of Negative Income Taxation, 1966 Wrs. L. Rev. 776 (1966).
} 


\section{B. Control of Personal Conduct}

With eligibility established, the recipient is now presumably entitled to his grant. Federal law imposes, with respect to the categorical programs, certain state-plan requirements that are prerequisite to obtaining federal matching funds. Requirements relevant to the recipient's freedom of choice center not only on the determination of need outlined above but also on conditions attached to payment of the grant itself. Under the categories, grants are based on a budget that covers most minimal requirements for living ${ }^{38}$ (not merely a selected few necessities, which were so often the focus under local and state programs of outdoor relief prior to enactment of the Social Security Act) and must be paid out in cash. ${ }^{39}$ The concept of money payment significantly differentiates public assistance as we have known it in the categorical programs since 1935 from old-style poor relief. Making payments in cash can be justified for administrative convenience. And money payments can be explained to symbolize society's conviction that in the majority of cases financial want stems from factors beyond individual control; at least, such was a popular view during the Depression. The policy also finds justification in an often-asserted belief that management of money aids the psychologically dependently inclined person to assert initiative and self-control, whereas relief in kind serves to reinforce dependent tendencies. ${ }^{40}$ Beneath the arguments about the form aid should take-cash or kindlies a sense of distaste for differentiating the poor as to their source of income by exposing them to food lines, placing distinctive clothing on their backs, and otherwise subjecting them to the indignities of daily identification. To be poor is bad enough; to be identified to the world as a pauper or welfare client is too much. It smacks of "badging," a practice long ago abandoned in original form but subtly perpetuated even now. ${ }^{41}$ And badging interferes with the urgent personal "need both to share and to withhold" communications from our fellow men. ${ }^{42}$

Money payments, therefore, are highly valued in any welfare scheme that strives to protect the privacy of the poor. The exceptions should be narrow; the original

\footnotetext{
${ }^{88}$ Report of the Advisory Council on Public Assistance, supra note 15, at 76; see also State Responsibility for Definiteness in Assistance Standards, Social Sec. Bull., March 1947, p. 29.

30 LEYENDECKER, op. cit. supra note 2, at 175-78; HaNDBook pt. IV, \$5roo-42. According to one authority, "the unrestricted money payments principle was written into ADC in 1935 not because of any special consideration to $A D C$ but primarily due to the fact that the legislators were thinking of old age assistance. They did not want the federal program to encourage the expansion of almshouses and county homes for the aged." Cohen, Factors Influencing the Content of Public Welfare Legislation, in ProceEDings, National Conference on Social Work, Social Welfare Forum 2 lo (1954).

${ }^{10}$ Charlotte Towle, Common Human Needs (1965).

41 Badging the poor, instituted in 1563 along with compulsory almsgiving for poor relief, was meant to curb the abuses of begging, and also perhaps to serve a deterrent function by stigmatizing the poor. Welfare clients today are identified as such to landlords, merchants, utility personnel, and so forth, by the requirements of eligibility investigation and redetermination. See text at note I9 supra. But see note 34 supra. Taking advantage of surplus food also requires identifying oneself to the world as poor. See

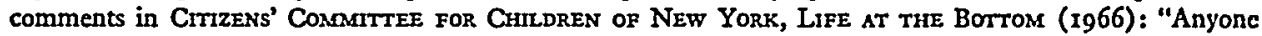
receiving welfare is automatically eligible for surplus food. . . . People wanting surplus food often must line up outside the depot, regardless of weather or shame at being on a bread line. ..." (Not paginated.)

42 Ruebhausen \& Brim, sipro note $I$, at 1189 .
} 
scheme under the Social Security Act limited them to situations in which appointed guardians and conservators would receive the funds. ${ }^{43}$ A shift in recipient population, ${ }^{44}$ however, may produce a reshuffling of social values. The introduction of protective payment provisions ${ }^{45}$ reflects a congressional decision that the disadvantage of persistent mismanagement of funds by recipients outweighs the values of a recipient's having unrestricted choice in expending money payments (to the limit of the modest grants, of course).

Under any scheme of income maintenance the gross mismanagers present painful choices to the policymakers. Public assistance-and especially AFDC, with its adult population drawn from an age group presumptively employable-is vulnerable to criticism that lack of restrictions on expenditures increases waste-and taxes. It is especially vulnerable today when the Great Depression is a mere flickering memory for many legislators and is soon to be an occurrence taken mainly on faith for new generations. The middle class, which once looked on public assistance as offering it salvation from want with some degree of dignity, wonders about the thrift and prudence of the residual risks presently receiving assistance, those persons "underemployed" or unemployed or, for any number of reasons, unprotected by the matured system of Old Age Survivors and Disability Insurance. To be sure, improvidence in personal expenditures may be a fault of OASDI beneficiaries, too, but the difference between social insurance and public assistance shields the beneficiaries from critical attention. Theirs is a contributory scheme; since they are said to have "earned" the benefits, it is theirs to spend at will (barring the extreme for which outside oversight is specifically authorized). Furthermore, because an average need is assumed, entitlement to insurance benefits entails none of the intimate budgeting process characteristic of public assistance, which allots so many dollars to food, so many to clothing, to personal supplies, and so forth, and thus conveys the implicit judgment that marked deviation from this carefully allocated division of expenditures is in itself evidence of mismanagement. But most important of all, perhaps, the privacy of the insurance beneficiary in this regard is protected significantly by the feeling that he belongs to a worthier class than the assistance recipient and should not be subjected to intensive personal scrutiny. ${ }^{46}$

Thus, in public assistance, the recipients are vulnerable to discretionary controls, and of all the categories of recipients none is more vulnerable than those receiving AFDC. It was, for instance, the initial program to adopt protective payments. In AFDC the purpose is care of children; extravagant adults do an injustice to their

\footnotetext{
${ }^{48}$ Social Security Amendments of $1958, \S 5 \mathrm{Ir}(\mathrm{a}), 72$ Stat. ro5I (1958), as amended, 42 U.S.C. $\$ 131 \mathrm{II}$ (x964) (authorizing payment to and management of expenditure of grant by judicially-appointed representative of recipient).

"See Perkins, AFDC in Review, 1936-1962, Welfare in Review, Nov. 1963, p. x.

${ }^{25} 79$ Stat. 415, 42 U.S.C.A. $\$ 5$ 306, 1206, 1355, 1385 (Supp. 1965). See Note, 1965 Amendments to the Social Security Act on Protective Payments to Aged, Blind, and Disabled, Welfare in Review, Dec. 1965, p. 26.

${ }^{8}$ See generally tenBroek \& Wilson, supra note 7 .
} 
dependent minors by imprudent patterns of expenditure. Protective payments, food stamps, rent screening justified within a "better housing" campaign-all are measures that can be used in AFDC and justified as positive aids for children. All equally produce side-effects; restricting personal choice and guarding the public purse are two examples. But the same paternalistic policies erupt in other programs. Wilkie v. O'Connor, ${ }^{47}$ the $194 \mathrm{I}$ New York case refusing assistance to an aged man who chose to sleep under a barn in a nest of rags, resisting all efforts to locate more conventional housing, puts the problem well. Using the gratuity theory, the court held that assistance might properly be predicated on acceptance of conditions related to his health and well-being. "One would admire his independence if he were not so dependent, but he has no right to defy the standards and conventions of civilized society while being supported at public expense."M8

Another illustration of the fusion of behavior control and income maintenance goals is found in policies respecting the morality of AFDC mothers. The catalyst of most cases presenting this issue is the "suitable-home" policy, which permits payments only to those parents with dependent children, otherwise eligible, who maintain such a home. Although in theory this policy can extend to other caretakers and to other kinds of personal behavior, in fact its application runs primarily to mothers whose sexual conduct elicits community disapproval. ${ }^{40}$ Disapproved behavior is usually inferred from the fact of giving birth to one or more illegitimate children. This leads one to wonder whether it is sexual immorality or the birth of potential public charges that is the object of attack. "Both" is possibly the answer. In any case the question that presents itself is the intrinsic soundness, in an income maintenance program, of legislative restrictions that relate to a mother's personal moral code or the legal status of the child.

We know that efforts to control sexual standards through the criminal law are pervasive and widely accepted. A variety of sexual acts engaged in by consenting adults are criminal, ${ }^{50}$ notwithstanding growing disapproval of laws proscribing conduct "that has no substantial significance except as to the morality of the actor." With notable exceptions, the criminal laws of the states include the offenses of fornication and adultery, to choose the ones most relevant to the issues arising in AFDC. But is the fact that fornication, for example, remains a crime necessarily a measure of the reasonableness of a test of personal morality in governmental programs of income support? Is it justification to "pry into the bedroom [and] cross

\footnotetext{
${ }^{47}$ 26r App. Div. 373, 25 N.Y.S.2d 6r7 (194I).

${ }^{4} I d$. at 375,25 N.Y.S.2d at $6 \mathrm{rg}$.

19 BeLl, op. cit. supra note I2, at I79; cf. SWEET, op. cit. supra note 24, at 41-48.

${ }^{\circ 0}$ See Morris Ploscowe, Sex and the Law (rev. ed. ig62). But see id. at I47; Model. Penal Code $\$ 207 . x$, comment at 205 (Tent. Draft. No. 4, 1955); Weyrauch, Informal and Formal Marriage-An Appraisal of Trends in Family Organization, 28 U. CH. L. REv. 88, 107 (1960), noting nonenforcement of criminal statutes on illicit sex relations.

${ }^{82}$ Model Penal Code $\S 207.1$, comment at 207 (Tent. Draft No. 4, 1955).
} 
examine the woman as to her relations with the male lodger..."?52 We do not look behind the existence of financial need in other programs. A finding of permanent and total disability qualifies a person for assistance whether the disability proceeds from a congenital defect or injury suffered in a drunken brawl, and continued receipt of support can be anticipated so long as conditions related to the disability are met. Yet immoral conduct, especially that which results in additional dependent children, can jeopardize continuance of AFDC..$^{53}$

It can be argued that legislative choice controls this outcome, that the support of disabled persons could have been limited to those whose disabilities accrued in a particular way. The example given may sharpen the issue. The reasonableness of measures of exclusion and inclusion turns on the purpose of legislation as to the relief to be afforded-income in this instance-and as to the universe to be served. Thus the issue, restated, becomes whether, having identified a population at risk, a legislature must include all persons within it as eligible for relief. If it need not, then worthy mothers may be included, unworthy excluded, and the legal questions resolve themselves into those directed at the fair bounds of administrative discretion in implementing statutes. These questions, in the example posed, would concern legislative intent as to the type of personal conduct rendering one ineligible and the legality of investigation procedures and of denial or suspension of benefits. At this level, as already noted, invasions of privacy may occur which are susceptible of judicial, as well as legislative or administrative, correction.

If, on the other hand, statutory measures must be all-inclusive of the population whose needs are their raison d'être then we may argue that a program established to provide support to children dependent as a result of absent, incapacitated, or otherwise insufficient parents may not exclude therefrom families with parents who disport themselves personally in ways disapproved of. Such a conclusion would drastically alter the present federal-state welfare system. Thus far in the categorical public assistance programs, the states are free to elect which subpopulations potentially eligible for federal matching shall be included. Some restrictions exist. The choice of subpopulation must not be wholly unrelated to the purpose of the program, as

\footnotetext{
${ }^{29} \mathrm{DE}$ SCHWEINirz, op. cit. supra note 2, at 194, quoting the Minority of the Royal Commission on the Poor Laws and Relief of Distress of xg09. Ironically, the comment was made in criticism of poor relief in a report favoring the very programs that give rise to this type of criticism today-publie assistance.

${ }^{83}$ The length to which welfare administrations go in scratinizing personal conduct is well illustrated in the following excerpt from the Louisiana Department of Public Welfare Manual:

"It is recognized that the client has a right to participate in social activities, including dating. The fact that a mother has dates with a man does not in itself establish that a nonlegal marital union exists [in which case deprivation of parental support must be established in respect to this nonlegal 'spouse'] ....

"If the mother is not known to have given birth to a child out of wedlock and does not have a past bistory of nonlegal marital unions, if both she and the man in question are legally free to marry, and if they are together during conventional, or acceptable hours of dating, the department would not presume that a nonlegal marital union exists.

"On the other hand, if either is not free to marry or if the client and the man stay away from home overnight, or he stays in the home to very late hours or overnight, or is in or out of the home at his will at all hours, this is not dating and a nonlegal marital union shall be presumed to exist." (\$ 2-742.J).
} 
automatic exclusion of illegitimate children from a program to aid needy children was said to be. ${ }^{54}$

The states, of course, need not participate at all in the grant-in-aid programs. Realistically, they seem bound to do so. Public support for certain kinds of income maintenance and the availability of federal funds for the categorical aids presage continuation of the nearly universal state participation in all programs..$^{55}$ State maneuvering room is limited in view of conditions imposed on receipt of federal funds. Choice of subpopulation is one of the few determinations that is significantly controlled by local law and policy. It is one remaining element among the shrinking number of state strategies for setting the direction of public policy and controlling local costs in public assistance. Its existence underscores the fact that the welfare "system," however much it has proliferated, is not a system but a series of measures with some overlapping and some yawning gaps. Its coverage and adequacy vary from state to state. And neither federal nor state government is yet compelled to offer relief to all in need. The omission of subpopulations from coverage in a particular state is doubtless regrettable; under the present system, however, it is surely permissible.

There is ample room for legislative activity. The pressures on individual recipients would be greatly eased, in all likelihood, by removal of residence requirements (as in the medical programs). Groups vulnerable to public disapproval could be somewhat protected by requiring a certain minimum of coverage; no AFDC matching at all, for instance, if AFDC-UP (AFDC for unemployed parents) is not also included. At a lower level, the disapproval of practices that expose and restrict recipient conduct can be translated into pressure for modifying administrative procedures or testing in the courts particular policies that appear to violate established rules of law. Thus, investigation of sexual conduct by means of midnight raids can be brought to court test. ${ }^{56}$ Means-test procedures can be replaced by simplified budgeting methods, and the federal agency would seem to be free to insist on uniform adoption of the latter if sure of their superiority. Aberrant policies, unrelated to program goals set by Congress, can be challenged under the conformity requirements.

Yet each of these approaches has its risks and weaknesses. Test cases require willing candidates, and in the nature of the assistance caseload they are hard to find.

\footnotetext{
${ }^{56}$ See BELL, op. cit. supra note 12, at 7I-72 (Social Security Commissioner questioned conformity of Georgia plan under state act denying aid to families where mother had more than one illegitimate child; act repealed a year after passage without having become effective); statement of Secretary Celebrezzc, March 26, 1963, disapproving a Michigan bill which defined unemployment of parent, for purposcs of AFDC-UP, to exclude parents ineligible for unemployment compensation on the grounds that the classification of unemployed parents was arbitrary and unreasonable; [1963-1964] Mrch. Arr'y GEN. Biennial Rep. 79 (No. 4I56).

${ }^{5 S}$ All states participate in OAA, AFDC, AB, APTD; a lesser number have combined the adult catcgories (Public Welfare Amendments of 1962 , $\$ 141,76$ Stat. 197 , as amended, 42 U.S.C.A. $\$ 5138 \mathrm{I}-85$ (Supp. 1965); AB, APTD, and OAA); 18 states have AFDC-UP to cover the unemployed parent; and 47 jurisdictions offer Medical Assistance to the Aged. See Program and Operating Statistics, Welfare in Review, Feb. 1966, pp. 24-29.

"Control of investigatory practices can also be exercised by the federal agency through the "state-plan" requirements. See note 34 supra.
} 
Uniformity of administrative practice is by no means an unmixed blessing; in a high-grant state the routine application of simplified budgeting methods may produce lower total grants in numerous cases. The result may seem justifiable to us; its virtues must, however, be consciously balanced against its limitations. ${ }^{57}$ As to nonconformity rulings the political hazards are high. Nonconformity pulls back federal funds; it risks individual security and produces public outrage. ${ }^{58}$ Occasional recourse to all these approaches is conceivably important for the dramatic educative value as well as for the merits of the case at stake.

In summary, then, governmental intervention into the lives of public assistance recipients is inevitable so long as dispensation of income maintenance proceeds on a determination of individual need. The inherently offensive aspect of need determination and redetermination lies not in investigating need per se but in the application of investigatory techniques and eligibility standards that are alien to the conduct of other governmental affairs and that reach, in our opinion, far beyond the point that honesty and efficiency in program administration reasonably require. The basic issues revolve around the attitudes we take toward less fortunate persons, the degree of double-checking assumed to be necessary to assure that legislative objectives are carried out, and the adequacy of payments to be provided. These issues have long been recognized. Tension between insistence on detailed punitive eligibility procedures and emphasis on elevation of public support programs to the position of "rights" is inevitable. In the ebb and flow of economic and political tides, the relative balance shifts back and forth.

But in our own century hopeful steps in the direction of a comprehensive and estimably-administered scheme of income maintenance have already been taken. Recognition that current programs degrade individual recipients by exposing them to a kind of scrutiny and control from which the rest of us are ordinarily exempt may

${ }^{67}$ Thus, Burns, arguing in favor of an income-conditioned pension type of assistance, states:

"A policy which provides that an individual, if he has no resources, can count upon a stated money sum (based, one would hope, on careful study of average family needs and expenditures patterns) would more truly reflect the concept of 'the right to relief.' It would give the recipient more leeway, and, provided he could make do on his allowance, his privacy would be respected." . Burns, What's Wrong With Public Welfare?, 36 Soc. SERv. REv. III, II5 (1962). But if, in reality, the attainment of relatively high-grant levels were contingent on detailed investigatory procedures, would the recipient appreciate the respect that the rest of us show his privacy? 'Is sacrifice of income increment warranted in order to enlarge his area of personal choice? That the issue is troublesome seems to be established by the fact that high-grant states are more reluctant to adopt simplified budgeting methods than the low-grant states. It is possible that simplified budgeting, and elimination of individualized investigation, promote values sufficiently important to the character of a democratic society that the recipient's view of the issue is not determinative. It should be recognized, nonetheless, that he may not share the high regard for protection of his privacy that others in society express.

${ }^{58}$ Only fifteen hearings to resolve conformity disputes have been called since the public assistance titles were enacted in 1935. Center on Social Welfare Policy and Law, op. cit. supra note i4, at ig-20. Unlike the sanction of "federalizing" state relief administration provided under the Federal Emergency Relief Act of $1933, \S_{3}(\mathrm{~b}), 48$ Stat. 56 , the sanction flowing from a nonconformity ruling is withholding of federal funds. Its severity has undoubtedly inhibited its use. BELL, op. cit. supra note I2, at 189-90. The 1965 amendment adding provision for administrative and judicial review of conformity issues, Social Security Amendments of 1965,79 Stat. 419, 42 U.S.C.A. $\$ 1316$ (Supp. I965), may lead to expanded use of conformity hearings as a technique of federal supervision over the assistance grants-in-aid. 
hasten further adoption of statutes, administrative procedures, and professional practices that are consonant with individual freedom and dignity.

\section{Expanded Treatment Services}

Government regulation of personal behavior-telling people how they should live-has been discussed thus far in coercive, punitive terms. Recipients are exposed in their quest for aid. Welfare officials become fraud investigators to make sure that only the economically and morally deserving receive assistance. The lever used by officials is simple and direct: assistance will be denied unless the recipient submits to investigation or, sometimes, to control over personal behavior-over moral conduct as well as over how the money is to be spent.

In recent years, welfare programs have begun to change; they are expanding from assistance programs to treatment programs. The 1962 amendments to the Social Security Act, ${ }^{59}$ and earlier ones in $1956,{ }^{80}$ announce the new philosophy of encouraging the states to institute or expand a variety of service programs: counseling, training, vocational rehabilitation, home management, and so on. The various programs of the Economic Opportunity Act take a somewhat similar approach. ${ }^{61}$ The poor, under the service approach, have many "needs," only one of which is financial.

Public efficiency (the desire to cut welfare costs) may partially explain the new direction; services associated with continuing eligibility requirements can be accounted for on this ground. Services for money management may be "services," but ultimately they are evaluated in terms of impact on public expenditures. Their rationale is to assure the public that income disbursed to promote the well-being of clients and families in fact reaches them in the form of food, clothing, or some other sociallyapproved commodities.

But the service approach also reflects humanitarian impulses; it rests on a conviction that more must be done for the underprivileged than can be effectively accomplished through financial aid. Despite the benign motives underlying services designed to rehabilitate, and despite the fact that on the surface services are voluntary for many recipients, administrative practices raise important issues.

One issue flows directly from federal policy. Services within the states are encouraged by a matching formula of funds, seventy-five per cent federal to twentyfive per cent state. ${ }^{62}$ To receive the federal share, states are bound to provide specified types of service and are encouraged by availability of federal funds to add even more. The federal policies establish differential treatment of the categories: ${ }^{03}$ AFDC is one where service is mandatory. ${ }^{64}$ Recipients in this category are not only universally

\footnotetext{
${ }^{80} 76$ Stat. 185 (1962), 42 U.S.C. $\$ \$ 601-05$ (1964).

${ }^{\circ 0}$ yo Stat. 848 (1956), 42 U.S.C. $\$ \$ 301-03$ (1964). See generally tenBroek, The 1956 Amendments to the Social Security Act: After the New Look-the First Thought, 6 J. Pun. L. I23 (1957).

${ }^{1} 78$ Stat. 512 ( 1964$), 42$ U.S.C. $\$ 273 I$ ( 1964$)$.

76 Stat. 173,175 (1962), 42 U.S.C. $\$ \$ 303(a)(4), 603(a)(3)(1964)$.

os See State Letter No. 606 transmitting revision of HandBooK pt. IV, $5 \$ 4000$ ef seg.

- The conclusion rests on the plan requirement added to AFDC in 1962: "A State plan . . . must
} 
presumed to have need of service; they are, unlike all other recipients, required to take it. ${ }^{\text {65 }}$

This compulsory factor, unique to one category, simply highlights a basic problem common to all: the recipient is vulnerable to the caseworker. The caseworker is still administering one program; but now it contains both assistance and service features. The official, then, is in position not only to impose assistance-type conditions (e.g., severing relations with a man) but also his own notions of what services a recipient ought to take advantage of to improve family functioning. Recipients become vulnerable not only to the punitive, moralistic official but also to the overzealous, wellintentioned but mistaken official, the social therapist who is certain that he knows what the client "needs." The services are voluntary for some and required for others. In every case, however, there are many ways by which the caseworker can persuade the recipient to follow his professional advice.

The power of the service-minded caseworker to impose his will arises principally from the fact that assistance determinations are not "either-or" propositions. The recipient, in addition to receiving basic sums to cover minimal recurring needs (rents, utilities, food, and so forth), will request from time to time money for a wide variety of special needs: extra clothing, club fees, tools for a child in work training, help in getting higher education for a child. These are important matters for the welfare recipient. They are authorized by statute but decided by the caseworker. They are discretionary decisions, and they arise repeatedly, particularly in the more progressive states, which exert themselves to offer the "extras." Unlike eligibility conditions, themselves matters for discretionary interpretation, the standards for service are so vaguely stated as to be undefined. ${ }^{38}$ Moreover, public expectations of the gains to come from services focus on rehabilitation, by which is meant the end of dependency. The expectations, nourished by the service amendments, rest on frail reeds; neither our limited knowledge of the pathways to rehabilitation nor the untrained, unstable work

... (13) provide for the development and application of a program for such welfare and related services for each child who receives aid to families with dependent children as may be necessary in the light of the particular home conditions and other needs of such child ..." 76 Stat. 185 (1962), 42 U.S.C. $\$ 602(a)(13)(1964)$. States are free to determine whether they will extend services to all families or only those whose children have special needs, but since investigation and planning for every family must precede selection of families to be served, the option for service resides with the states, not recipients. Screening is mandatory on all, and services on those selected therefor. For a state electing to extend service to all AFDC recipients, see Ill. Dep't Public Aid, Release No. 63:8, Manual (I963).

${ }^{65}$ Ibid. Ten years ago tenBroek noted dangers associated with the service program which have to some extent been realized in subsequent experience. See tenBroek, The 1956 Amendments to the Social Security Act: After the New Look-the First Thought, 6 J. PUB L. I23, I45 (1957). See also Schorr, The Trend to $R x$, Social Work, Jan. 1962, pp. 59, 64-66.

${ }^{B S}$ See, e.g., the statement of purpose in AFDC:

"For the purpose of encouraging the care of dependent children in their own homes or in the homes of relatives by enabling each State to furnish financial assistance and rehabilitation and other services, as far as practicable under the conditions in such State, to needy dependent children and the parents or relatives with whom they are living to help maintain and strengthen family life and to help such parents or relatives to attain or retain capability for the maximum self-support and personal independence consistent with the maintenance of continuing parental care and protection ..." 70 Stat. 848 (I956), as amended, 42 U.S.C. $\$ 601$ (1964). 
force that carries out the public's will promises much hope that services alone will produce desired results. ${ }^{67}$

And were there assurance of achieving the desired ends, the levers of compulsion or imbalance of power possessed by caseworker over recipient would still raise the question of how voluntary is the recipient's engagement in the "helping" process. For the recipient is likely to feel (and he or she may be right) that more of what is important will be forthcoming if there is a show of cooperation with the caseworker's suggestions for self-improvement.

The new welfare programs expand the areas of official concern into additional aspects of private life and personality. If the character of a recipient is to be changed in order to better equip him for life, then techniques must be used to explore social and psychological defects. The programs legitimize governmental concern in those matters that affect the process of rehabilitation. The price of rehabilitation is the increased vulnerability of welfare recipients to the humanitarian regulator of personal life.

\section{III}

\section{Privacy Issues in the Administration of Juvenile Justice}

A moment's reflection will reveal the striking similarities between the adminstration of welfare services and the administration of juvenile justice. The target populations are more or less the same. Delinquency is rising in the suburbs, but the major source of supply for the juvenile justice system comes from lower socioeconomic classes. Both the welfare and juvenile-justice systems are characterized by officials exercising enormously wide discretionary authority. In both systems the clients are extremely vulnerable to all sorts of state control. In both systems the officials can employ coercive powers-in juvenile justice, custodial institutions; in welfare, the denial of assistance. In both systems governmental intrusions and control over personal life are justified on the same ideological basis: the programs are to help the clients, not to punish them. In the newer welfare programs, treatment goals legitimize increased governmental control; this is a well-established phenomenon in juvenile justice. Welfare statutes are only a starting point for the examination of the reach of government into the lives of disadvantaged people. Similar issues are raised in the administration of juvenile justice.

\section{A. Delinquency}

Official interventions in the lives of adolescents and their families are based initially on broadly defined statutes. Definitions of delinquent vary from jurisdiction to jurisdiction. Generally, the term has been defined to cover youthful perpetrators

\footnotetext{
${ }^{87}$ See Departmental Task Force on Social Work, Education and Manpower, U.S. Dep't op Health, Education, and Welfare, Report, Closino the Gap in Social Work Manpower (1965). Compare AIIEN, Op. cit. supra note 4 , at I2-16.
} 
of $(a)$ acts that would be criminal if committed by adults; $(b)$ acts that violate civil prohibitions (i.e., violations of "any county, town, or municipal ordinance"); or (c) violation of vaguely defined catchalls that seem to express the notion that the adolescent, if allowed to continue, will engage in more serious conduct. In this latter category, one finds statutes proscribing associations with "vicious or immoral" persons, running away from home "without just cause," and using vile, obscene, or vulgar language, as well as conduct leading to the conclusion that the youth is "incorrigible," "disorderly," "given to sexual irregularities," "beyond the control of parent or guardian" or that he "so deports himself as willfully to injure or endanger the morals or health of himself or others." 68

In many jurisdictions, the statutory definitions have not been narrowed by judicial construction; adolescents are held as "delinquent" for only minor misconduct: carelessness, truancy, mischief, running away from home, ungovernability, petty sex offenses, or because of environmental circumstances. ${ }^{69}$ If an adolescent is adjudged "delinquent," he can be put on probation and subjected to various degrees of supervision, removed from his home, or institutionalized. Some courts have used bizarre or cruel sanctions: "short shock periods of confinement," "thirty-day confinements at work camp for children who defy court's order to refrain from driving," "essays and home improvement projects," deliberate publicity about the adolescent's crime and public identification of him and his family, and, finally, "washing police cars."7o

Historically, the court was the center of juvenile justice reform activity; even today it still receives most of the scholarly and reform attention. However, quantitatively if not qualitatively, the police and court intake probation staff seem to play far more significant roles in the control of delinquency. Almost all (over ninety-eight per cent) of the delinquency cases are referred by the police. The FBI estimates that about half of the cases are handled within the police department; estimates of the Chicago Police Department, Youth Division, run as high as seventy per cent. Of the cases referred to court (for one reason or another deemed incapable of handling by the police), about half are handled by the court intake probation staff. In other words, about eighty per cent of the adolescents taken into custody for delinquency probably never get to court. ${ }^{\mathbf{7 1}}$ Figures on the pre-court aspects of the system are hard to come by, especially since it is impossible to estimate how many police contacts are never recorded. But it is clear that the overwhelming majority of delinquents taken into custody never see a juvenile court judge.

If adults are taken into custody but not brought before the courts, the case is

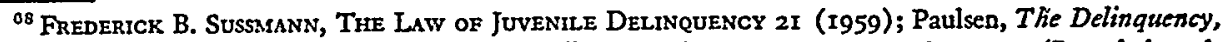
Neglect, and Dependency Jurisdiction of the Juvenile Court, in JUSTICE FOR THE CHID 49 (Rosenheim ed. Ig62).

${ }^{\circ 0}$ Handler, The Juvenile Coutr and the Adversary System: Problems of Function and Form, 1965 Wis. L. REv. 7, 15.

${ }^{70}$ Note, Juvenile Delinquents: The Police, State Courts, and Individualized Justice, 79 HARv. L. REv. 775, 807 (1966).

${ }^{71}$ Compare id. at 776 .
} 
dismissed; the arrestee is returned to society relatively free from official regulation (although there may be continued surveillance or harassment). This does not necessarily happen when an adolescent is taken into custody for a delinquent act but is "screened out" before getting to court. The police and intake staff have developed elaborate systems of regulating the conduct of adolescents and families. The leverage that the police and the intake staff have is the threat of court referral: if the adolescent and his family do not cooperate, the case will be referred to court. The adolescent will have a permanent court record that may hurt him in later life; he will be stigmatized; he may be removed from the home; and he may be institutionalized.

It is known that the police also regulate adults unofficially by the threat of formal proceedings: arrest, police records, prosecution. But there are significant differences in the ranges of power that the police have with adolescents as compared with adults. The statutory definitions of delinquency are considerably broader than definitions of criminal behavior; the role of the police in administering the juvenile system is correspondingly broader. In addition, it is easier for the police or the intake staff to apply the lever of court referral, since broad statutory definitions can be made to fit most cases. With adults, procedural requirements attempt to restrict the basis on which police can arrest, search, or question persons suspected of crime. To a large extent, these restrictions do not apply to the relationships between the police and juveniles. In juvenile justice, the police have broader discretion to investigate adolescents and/or take them into custody; without a warrant, an officer can take into custody and detain a child if the parents are unavailable or the officer considers the parents incapable of coping with a minor form of deviance.

What are the criteria that the police use in regulating delinquents? ${ }^{72}$ The Manual of Procedure of the Youth Division of the Chicago Police Department sets forth an instructional guide for its officers on how to handle juvenile cases. ${ }^{73}$ There are three basic dispositions that an officer is authorized to make:

r. Community Adjustment. Releasing the juvenile to his parents or guardian without the need for further police action. In some instances there may be need for a follow-up by the youth officer to determine the juvenile's progress.

2. Community Adjustment and Resource Referral. Releasing the juvenile to his parent or guardian, in addition referring the child and his parent or guardian to a resource agency or organization in the community, in the light of the needs of either the juvenile or the family or both.

3. Juvenile Court Filing. Immediate detention of the juvenile at the Audy Home, or temporary release of the juvenile to his parent or guardian, to be followed by conference at the Complaint Division of the Juvenile Court. ${ }^{74}$

\footnotetext{
${ }^{72}$ Most of our information about the Chicago Police Department's handling of juveniles is attributable to Herman Goldstein, Assistant Professor of Law, Wisconsin Law School.

73 Youth Division, Chicaco Police Department, Manunl or Procedurx (Nov. 1965) [hereinafter cited as MANUAL.].

"MaNual IIt.T.4.
} 
The officers are given six guidelines in exercising their judgment as to which disposition to choose. The guidelines are stated separately but are interdependent:

r. "Type and seriousness of the offense." The Manual calls for court filing if a serious offense ("usually classified as a felony") is committed by "an older juvenile." Different treatment may be used if the same offense is committed by "a child of tender years" unless there is a "strong need for help which could only be obtained through court filing." Discretion is even broader with minor offenses ("the type of behavior frequently referred to as Disorderly Conduct"). "Some consideration should be given to a Community Adjustment ... where no serious negative considerations arise in respect to the remaining guidelines." Interventions may be based on minor misconduct or a disturbed environment. "Sometimes this type of situation [a series of minor offenses] might be more in need of attention than one where an isolated and more serious offense has been committed...." "Even a minor offense, which might not in and of itself warrant a court filing, could require such filing for purposes of removing the child from his home for reasons of neglect or dependency."

2. "The previous behavioral history of the juvenile." The officer is instructed to consider the record of the child-both the Youth Division record and the officer's personal knowledge, if any. If there is a "previous history indicating that the juvenile has been involved in a series of other minor offenses all of which were adjusted without court filing ... consideration should then be given to the possibility of court intervention no matter how minor the offense charged.... [But] even here a careful exploration of all possible avenues of help would be advisable before a court filing."

3. Environmental factors, including the dispesition and capacity of the juvenile. A Community Adjustment, says the Manual, contemplates a change in "elements having a deleterious effect upon the juvenile" and the "capacity of the juvenile to change his behavior and to accept help." Accordingly, the officer must investigate the "neighborhood and the negative forces at work there," "family relationships," "school problems," and the "juvenile's own makeup and temperament."

4. The attitudes of the parents and "their ability to provide the necessary supervision and guidance." The Manual reminds the officers that in many situations the attitudes and abilities of the parents are important "whatever disposition is eventually made," particularly "as insuring that ... plans ... for referral to a community agency will be carried forward by them." "The youth officer is interested not only in the parents' attitude toward the child, but the view they take of the offense committed." "A home interview enables the youth officer to observe the child in his family setting, and therefore helps him to make a more selective and meaningful disposition."

5. The attitude of the complainant. The complainant has the right to insist on a court filing if an offense has been committed and "there are reasonable grounds to believe the juvenile in question is implicated." But, "most persons will agree with an intelligent plan of rehabilitation ... when careful and painstaking explanation is made regarding the proposed plan for a Community Adjustment." 
6. Community resources. In some situations, the child's family is a sufficient resource. In other situations, the officer will refer the child and/or the family to community agencies when the family needs additional help with the child or when "other members of the family ... are in need of assistance and counseling."75

The above procedures relate to "delinquency"--where the adolescent may have committed what would have been a crime if committed by an adult, or a violation of a civil prohibition or is guilty of lower forms of misconduct. The lightest disposition is the Community Adjustment. The adolescent is returned home, but there may be continuing supervision by the youth officers of varying degrees of severity. According to the Manual, three factors enter into the officer's decisions as to whether to impose Community Adjustment. One is objective-the offense has to be of a minor nature. The other two are subjective-the adolescent has to appear to "have such personal controls as would make the repetition of the offense unlikely," and his parents must "give every indication of a wish to cooperate and to provide the necessary supervision." The adolescent and the family may have the proper attitude, but the officer may still think that they are unable to cope with the situation. If a community agency is available to give what the officer thinks are the necessary services, the officer may refrain from court filing. Of course, if the adolescent and the family decline to use the community services, the case will be referred to court. If the offense is serious, or if there have been a series of minor offenses and previous failures of Community Adjustment, or if the parents are incapable of providing the necessary supervision, the case will be referred. The adolescent may be taken into immediate custody if he (I) "has a history of running away and is likely not to appear at the [court] conference"; (2) "has committed such a serious offense as would indicate that he might be a danger to the community or to himself"; or (3) "cannot be controlled by his parents or they exhibit a lack of cooperation." ${ }^{.77}$

The Manual tells the officer how he should exercise his authority. The extent to which officers behave in accordance with the Manual is, of course, an empirical question. There is evidence that in some jurisdictions officers rely on race and demeanor in deciding whether to take an adolescent suspected of delinquency into custody and the type of sanction to impose. ${ }^{78}$ The juvenile and the family have to show the officer what he thinks is proper respect and have to view the situation with appropriate seriousness. Community adjustment will be forfeited if the juvenile or the family is cavalier or indifferent (i.e., "cool") and, of course, if they are hostile. Challenging the officer's authority, including asking for legal assistance, is not the proper attitude; the sanction will be court referral.

Community Adjustment (or its equivalent in other areas) is a continuing process;

\footnotetext{
${ }^{70}$ Id. at IIr.I.I, 2.

${ }^{20}$ Id. at III.I.4.

${ }^{77}$ Id. at III.1.5.

${ }^{78}$ See Note, supra note 70 , at 782 .
} 
its substantive character also varies with the jurisdiction. The Kansas City police administer a program called "grounding":

A typical "grounded" youth must attend school unless a doctor's explanation is obtained for his absence. At all other times he may leave the house only if accompanied by a parent, and then not for any activity that is primarily engaged in for pleasure. He must dress conventionally and have his hair cut in a reasonable manner; and he must study at home for a minimum prescribed period each day. After this schedule is enforced for a month, lesser conditions will be imposed for duration of the school year. ${ }^{79}$

Officers may require standards of conduct that in their judgment are indicative of good behavior: obedience to parents and school authorities, regular school attendance, participation in approved social activities, or regular church attendance.

In Chicago, Community Adjustment decisions are usually handled at the precinct station. The youth officers have separate offices for conferences with the adolescents and the families. Depending on the regulation imposed, follow-ups may be conducted in the street, the home, with school authorities, or with social agencies in the community. Other jurisdictions have more elaborate procedures. In some jurisdictions, the police conduct hearings of a somewhat formal nature. Notice of the time and place of the hearing is sent or delivered (by a patrolman) to the family. The adolescent and the parents appear before a "hearing officer" or "counselor" (who is a uniformed officer) at the station. The hearing officer sits behind a desk and quasi-judicial formalities are used, but the adolescent and family are not advised of the right to have counsel or the right to remain silent. It is extremely rare for counsel to appear. The purpose of this procedure is to "solemnify the inevitable lecture to the juvenile and to increase the chances that he will confess." sistent denial of guilt is taken to indicate that the juvenile is not amenable to the 'noncompulsory' approaches of his parents, local agencies, or the police, and requires referral to court." ${ }^{21}$ There is no authority for compelling attendance at these hearings; again, the leverage is court referral and police records.

When a delinquent case is referred to court, the intake probation staff "screens" it in much the same manner as the police. Informal probation is used as an alternative to court referral. The intake staff, like the police, consider age, attitude, history, family situation; what the adolescent did is not of great importance, unless the act was a serious offense. In a few jurisdictions, informal probation is authorized legislatively and is subject to more or less judicial control. ${ }^{82}$ In most jurisdictions, however, this is not the case. The leverage used by the probation staff is the same used by the police-court referral-with one important addition: the probation staff files an evaluation report on the adolescent which is usually very influential in any subsequent

\footnotetext{
${ }^{20} I d$. at 784 .

${ }^{80} \mathrm{Id}$. at 780 .

o1 Id. at $78 \mathrm{r}$.

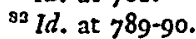


judicial disposition. Extended informal probation is buttressed by threats of "dire consequences should ... [the adolescent] fail to behave." ${ }^{\prime 3}$

\section{B. Dependency and Neglect}

Statutory definitions of dependent and neglected also vary from state to state. In some states, no distinction is made-a child may be "dependent or neglected," with a single definition. Generally, however, neglect seems to contain the notion of fault on the part of the parents in failing to provide proper care for children, and dependency refers to the inability of the parents to provide such care. In any event, the statutory definitions of dependency and neglect are very broad and include such phrases as "destitute, homeless or abandoned"; "a home which by reason of neglect, cruelty or depravity on the part of the parents ... is an unfit place"; "has not proper parental care or guardianship." ${ }^{44}$ The Iowa statute concludes with "such other unfit surroundings to bring such child, in the opinion of the court, within the spirit of this chapter." ${ }^{85}$

One extreme act of abuse may satisfy statutory standards, but usually an adjudication of dependency or neglect requires a protracted failure on the part of the parents..$^{88}$ Persistent physical cruelty, flagrant sexual immorality, or total abandonment should, in most situations, be enough for the court. Short of extreme situations, neglect depends on the court's assessment of the home environment. Parents are not held to the highest moral standards, but it is difficult to predict what types of deviancy will constitute lack of parental care. Conflicts over religious opposition to needed medical attention for children represent some of the more dramatic dilemmas faced by the courts. Sanctions in dependency and neglect cases vary with the type of misconduct involved. Generally, parental rights are not terminated unless the conduct is serious. Most often custody will be changed without terminating parental rights, though the absence of the child may loosen meaningful parental ties. ${ }^{87}$ In less extreme cases, the court might provide for counseling and other forms of supervision in the home.88

There is little information on the administration of dependency and neglect cases at the police or intake levels. The Chicago Youth Division Manual defines neglect in terms of "unsafe premises," "lack of sanitary facilities," "lack of heat," "danger of fire," "vermin or rodent infestation," "malnourishment," inadequate clothing, "exploitation and overwork," "exposure to vice situations," lack of attendance for long periods of time, "undue family friction and marital discord," mental illness of the

\footnotetext{
8s Tappan, Unofficial Delinguency, 29 NEs. L. REv. 547, 554 (I950).

8s See Paulsen, supra note 68, at 63; Rosenheim, The Child and His Day in Courf, Child Welfara Jan. 1966, p. 17,21 .

"IOWA CODE $\$ 232.2$ (7) (1962).

${ }^{80}$ Rosenheim, The Child and His Day in Coutt, Child Welfare, Jan. 1966, p. 17, 22.

${ }^{87}$ Cf. In re Bonez, 266 N.Y.S.2d 756 (Family Ct. 1966).

${ }^{88}$ Paulsen, supra note 68, at 65-66.
} 
parents, and "lack of proper supervision." If an officer decides that a child is neglected, he may refer the child and the family to an agency if the "needs of the child and the family ... [can] be met by the agency," "the family ... [will] cooperate," and an "agency ... [is] available and willing to work with the family." The officer is also authorized to remove the child from the home if he is "in immediate danger of being physically, morally, or emotionally harmed." But "the youth officer must avoid being stampeded into the removal of the child by reason of the apparent emergency." 90

The Youth Division Manual does not list Community Adjustment as an appropriate disposition for dependency and neglect cases; such cases are to be referred to court or to a social agency, or the child is to be taken to a special custodial institution. Is there nevertheless some sort of informal police regulation? The police certainly have sufficient power. In investigating a juvenile case, the officer is not restricted to only one statutory category. "The Youth Officer, when processing a young child for a delinquent act, should be alert for evidence of abuse or gross neglect by the parents ... of such child." Even if an act of delinquency does not warrant court filing, the officer may still remove the child "for reasons of neglect or dependency." The multiple and easily transferable bases of official intervention increase the officer's leverage over the child and the family.

Do the police, then, attempt to improve family functioning in neglect and dependency situations which they do not regard as sufficiently serious to warrant formal proceedings? We don't know. The Youth Division claims not. They say (and it seems plausible) that the police do not regard neglect and dependency as "normal" police functions. ${ }^{92}$ Delinquency is regarded as essentially crime detection and prevention. ${ }^{83}$ The police do handle many neglect and dependency cases, but the cases are usually thrust upon them. Neighbors call and complain about battered or abandoned children. Quite often the police simply find small children wandering the streets late at night. The police say that they attempt to refer all cases to social agencies, even if they are deemed sufficiently serious as to warrant immediate removal from the home. The police are on duty twenty-four hours a day, and, of course, they encounter neglect and dependency situations at times when referrals are difficult. But in general, the Chicago police do not appear to have an elaborate regulatory system for dependency and neglect. But what happens, then, with the cases that are referred to the social agencies? Do they refer all cases to court? This seems unlikely. Do they then engage in extensive regulation using the threat of court referral as leverage? We have no reliable information on these questions.

\footnotetext{
${ }^{89}$ MANUAL V.5.3.

${ }^{20}$ Ibid.

${ }^{91}$ Ibid.

* Chicago police officers have said that finding 2 dependent or neglected child is like getting 2 fat tire on patrol: the officer is temporarily "out of commission."

${ }^{3}$ The opening statements of the Manual read as follows: "As part of a law enforcement agency, we have given primary consideration in the determination of our procedures to the goal of preventing and suppressing delinquent and criminal conduct. This is the mission to which we are sworn." Manuaz. iv.
} 


\section{Privacy Issues}

The administration of juvenile justice, then, results in extensive regulation of personal and family behavior. The apparatus of the state is concerned not only with aggressive criminal conduct but also with school problems, child rearing, and moral behavior. Families and adolescents coming into contact with the system are required to do things not required of others, or they must refrain from activities others are allowed to enjoy. To a great extent, regulation is imposed without court sanction or control. Regulation is extensive substantively, and it is not subject to what are normally thought of as due process controls.

The regulatory reach of the state sprouts from all the levels in the juvenile justice system. In the first instance, the regulatory power is derived from legislation. The legislature defines the very broad terms delinquent, dependent, and neglected. It defines the juvenile court jurisdiction and authorizes the court to adjudicate and dispose of juvenile cases. Institutionalization, terminating parental relationships, and other punitive sanctions and deprivations of liberty stem from legislative commands. The legislative structure is also largely responsible for the administrative practices of the police and the intake probation staff. Traditional police detection and preventive activities are authorized by the statutes. The areas of police investigation in the administration of juvenile justice are broader and more numerous than the areas investigated in administering criminal statutes. But the expanded jurisdiction in juvenile justice is not the result of the police arrogating to themselves tasks that do not belong to them legitimately; the legislature has told them to investigate these areas. Directions in the Chicago Youth Division Manual to investigate home conditions, attitudes of adolescents and families, and school difficulties are interpretations of statutory commands.

It is misleading to view Community Adjustment, informal probation, and the roles of public and private social agencies as beyond the pale of legitimacy. It is true that most informal adjustment is not specifically provided for legislatively, but these extensive regulatory practices are known; they are acquiesced in by the legislatures and the courts; and, at least as far as the police are concerned, some aspects of their regulatory activity are appropriate features of the discretion of law enforcement officials. Of course, some of the activities of the police and the intake staff are $u$ nnwarranted; in administrative law terms, they are beyond the scope of delegated authority. But it is important to recognize that much of the structure of the administration of juvenile justice is the result of legislative command.

The substantive reach of the administration of juvenile justice is also the result of conscious policy choice and colors the regulatory activities of officials throughout the system. The ideological basis of juvenile justice is treatment.

The essential spirit of the juvenile court has never been better expressed than in a statement made by the late Judge Edward F. Waite more than four decades ago. According to Judge Waite, the crucial distinction between the traditional criminal 
court and the juvenile court is that between a court which directs its efforts "to do something to a child because of what he has done," and a court concerned with "doing something for a child because of what he is and needs." This distinction, so felicitously expressed, points to very real and significant differences in orientation. ${ }^{94}$

The single criminal act-what the adolescent has done-is important primarily as a symptom of broader personality or environmental needs. Thus, no distinctions should be made between the delinquent and the dependent or neglected. The adolescent (whether delinquent, dependent, or neglected) needs understanding, guidance, and protection; juvenile justice is individual treatment. ${ }^{95}$

The treatment orientation supports the extensive substantive regulation in the system. The theory behind judicially-imposed essays and home improvement projects is obvious, if misguided. "Judge Gardner of Santa Ana specialized in short shock periads of confinement, a punitive measure he thinks effective." Similar "therapeutic" practices are not uncommon, ${ }^{97}$ and the police and the intake staff are no less inclined to indulge in them than are the courts. It is probably true that most of these officials have a genuine interest in the adolescents and the families and think that they are performing valuable rekabilitative services for them. The Youth Division Manual is the product of highly motivated police officers, the School of Social Work at Loyola University, and private agencies. The Manual tries to professionalize and humanize police work with children. It tries to guide the police in exercising their discretion, and it fully recognizes that adolescents in trouble are different from criminal adults. At the very least, the police and the intake staff feel that if adolescents charged with delinquency and their families will work with them, the harsher results of the formal proceedings-police records, the stigma of being labeled a "delinquent," and perhaps removal of the adolescent from the home and institutionalization-can be avoided. The police and the intake staff regulate not because they want to punish, but because they feel that they can best fulfill the treatment goals of the program. They want to "give the kid a break."

Moreover, it should be recognized that the Chicago effort has been accomplished in the face of great odds. The Manual and the Youth Division had to grow in a department that was not committed to the philosophy of juvenile justice. Traditional police officers draw little or no distinction between the youthful and adult offender. They have a thinly veiled contempt for the juvenile justice system-youth officers in the Chicago Department are referred to as "diaper dicks" by their fellow officers-and they regard the procedures of the Manual as "coddling" and as merely perpetuating criminal tendencies.

\footnotetext{
06 AlLEN, op. cit. stcpra note 4, at I7-I8. (Footnotes omitted.)

${ }^{\circ 0}$ See Handler, The Juvenile Court and the Adversary System: Problems of Function and Form, 1965 WIs. L. REV. 7, 9-10.

"Note, suspra note 70 , at 807 .

${ }^{97}$ Lecture by Judge Arthur L. Dunne, Magistrate, Circuit Court of Cook County, Illinois, at the University of Wisconsin Law School, March I4, 1966.
} 
The tailored-treatment philosophy of juvenile justice serves to broaden further the administrative discretion of officials. Remote areas of family life and personal conduct are proper subjects of official concern. Confessions and displays of appropriate manifestations of seriousness, respect, and deference are not simply to make police work easier; attitudinal changes are considered by the police, the intake staff, and the judges to be preconditions of treatment. A youth cannot be "helped" unless he has recognized his guilt and is willing to be rehabilitated; a person cannot be treated if he thinks that he has been accused unjustly. Statutory language, ideology, perhaps rationalization, all serve to legitimize the penetration of government into the mind itself. It seems curious, in a way, that the "new" social welfare programs are now catching up with the youth officer on the beat; the rhetoric of the juvenile court reform movement, at the turn of the century, was not too dissimilar from the rhetoric of the War on Poverty. ${ }^{98}$

The pervasiveness of the juvenile justice system of regulation is staggering, but it is obvious that the system could go further, if we are willing to pay the price. Expanded search and interrogation techniques by law enforcement agencies would probably result in the apprehension of more criminals and the prevention of more crime. Expanded regulation need not, however, assume overt punitive and surveillance characteristics; it too can be rehabilitative or treatment-oriented. It has been suggested, for example, that "crime-prone" areas of cities (i.e., poverty-stricken areas) be subject to massive welfare services, including educational programs for parents, to reduce crime and delinquency. Incentives could be used to stimulate voluntary cooperation. School officials could identify students "in difficulty" who then would be subject to special programs to prevent incipient delinquency. ${ }^{.0}$ Programs of this nature blur the line between law enforcement and publicly-administered welfare; but this presents no conceptual problem for juvenile justice since, as we have seen, the ideology of that system is treatment-oriented to begin with. The line between coercion and freedom of choice is also blurred, but the distinction, as we have implied, is already hazy. A potential school drop-out, or a state-selected family for special counseling services, does not have to accept the offer of official "help," but the consequences of refusal can be made clear. ${ }^{100}$ An adolescent does not have to accept Community Adjustment, either, if he prefers a police record, court referral, and possible institutionalization. Programs to prevent delinquency, dependency, and neglect can be expanded, but, however labeled, they will be expansions of official regulation of private lives.

Proposals to restrict the scope of juvenile justice also involve a balancing of costs

\footnotetext{
${ }^{98}$ The rhetoric that was spoken at the turn of the century is presented in Rosenheim, Juvenile CourtReality or Ideal, Juvenile Ct. Judges J., Winter 1965, p. 25.

"S See Prevention and Control of Crime and Delinquency, Final Report (report prepared for the California Youth and Adult Corrections Agency, I965).

${ }^{100}$ For problems in drawing the line between voluntarism and coercion in official-client relatione, see Handler, Controlling Official Behadior in Welfare Admivistration, 54 CAL1P. L. Rev. 479 (1966).
} 
against gains. The more radical proposals would allow state interference, in the case of delinquency, only if the adolescent has committed an act that would be a crime if committed by an adult. The state would have to prove its case against the adolescent according to procedures far more rigorous than the informal procedures of most present-day juvenile court proceedings. Judicially imposed dispositions would be based on what the adolescent did, not on what the court or the probation staff thinks he "needs." In dependency and neglect cases, the state would be allowed to take a child from the home only in the most severe cases-extreme brutality, for example-and not because officials disapprove of the moral behavior or child-rearing practices of parents. ${ }^{101}$

A number of justifications are advanced for cutting back the scope of juvenile justice. Some are based on ideology, a preference for maximum freedom of the individual in family matters except where the threats to the security of the child or society are very clear. Others stress the difficulties of administering the juvenile justice system. Depending of course on the particular adolescent and family involved, treatment-oriented individualized justice may result in coercion, manipulation, cynicism, fear, or bewilderment. Matza claims that in the eyes of the adolescent, the system represents rampant injustice. ${ }^{102}$ Efficient law enforcement prevention and detection techniques appear as discriminatory regulation. Differential disposition (both formal and informal) based on family and home situations or the adolescent's "problems" and "needs," rather than what he did, appear grossly unfair. Standards for enforcement and disposition appear nonexistent. The lack of perceived standards and what appears to be injustice run riot-that is, the family's extreme uncertainty as to how to cope with the system-serve, in turn, to increase the leverage that the officials have over the adolescents and the families. Extremely broad legislative and administrative authorizations are further broadened by the psychological reactions produced by the system in the minds of the adolescents and the families.

The juvenile institutions are often no different from adult prisons, and sometimes they are worse. ${ }^{109}$ If the state is, in effect, incarcerating adolescents as if they were adult criminals, then the adolescents should be held to the same minimal standards of conduct and afforded the same procedural protections as adults. In dependency and neglect cases, the child is taken from the unsuitable home but is then subjected to a series of inadequate, mismanaged, and ill-supervised foster homes. The press of large city dockets converts the juvenile court hearings from an informal father-son session to an assembly-line processing. Furthermore, it is claimed that in fact most judicial decisions are based on what the adolescent did and not on what he needs. The rhetoric is hypocritical at the least; more often it is destructive of sound correc-

${ }^{101}$ See, e.g., AlLEN, op. cit. supra note 4, at 18-24; Paulsen, supra note 68; Tappan, Juridical and Administrative Approaches to Children with Problems, in JustrCe FOR THE Crind I44, I66-68 (Rosenheim ed. 1962 ).

108 David Matza, Deimeuency and DRift ch. 4 (I964).

${ }^{103}$ See Albert Deutsch, Our Rejected Children (I950); Paud W. Tappan, Juvenile Deuinquency 430-31 (1949). 
tional goals. ${ }^{104}$ Most significant, however, is the growing feeling that our present state of knowledge is incapable of giving even the wisest of men a sufficient basis for knowing what is "best" for adolescents and families. The problem is compounded when the decisions are made by inadequately trained police officers, probation staff, social workers, and juvenile court judges. ${ }^{105}$

The call to re-introduce criminal law procedures reflects a concern for the integrity of the individual. ${ }^{106}$ The adult offender is tried for a specific act. In most instances, his history and personality are not on trial. He has counsel to insist that evidence be relevant to the issue. Prohibitions concerning search and seizure and confessions give the individual additional protections from official interventions. In theory, at least, the adult offender is not exposed to investigations of psychological needs and official notions of therapy until after conviction. The situation is different in juvenile justice. The vague statutes and the treatment philosophy authorize officials to roam at will in the minds and lives of juveniles and families.

The latest juvenile justice reform statutes attempt to reflect this concern for the integrity of the individual. The Illinois Juvenile Court Act of $1965^{107}$ (which follows closely the California and New York statutes) ${ }^{\mathbf{1 0 8}}$ introduces many procedural changes. Standards are tightened for the temporary custody of children, the timing of court hearings, dispositions, and the use of records by outside agencies. The most significant procedural changes concern the court hearings. The hearing is bifurcated into "adjudicatory" and "dispositional" hearings. The former is to determine whether the adolescent is within the jurisdiction of the court (e.g., whether he committed an act of delinquency); the latter is to determine what treatment should be undertaken if the adolescent is found to be "a ward of the court." Civil rules of evidence apply in the adjudicatory hearing. The allegations must be supported by a preponderance of the evidence. Findings cannot be based "solely upon the uncorroborated extra-judicial admission or extra-judicial confession of a minor."100 There is a right to counsel (including court-appointed counsel, if necessary), to be heard, to present material evidence, to cross-examine witnesses, and to examine "pertinent court files and records." 110 The scope of the dispositional hearing is broader. In the words of the statute,

After adjudging the minor a ward of the court, the court shall hear evidence on the question of the proper disposition best serving the interests of the minor and the public. All evidence helpful in determining this question, including oral and written

\footnotetext{
${ }^{104}$ See MATZA, op. cit. stupra note 102, at 133-34.

${ }^{105}$ The United States Supreme Court has recently expressed misgivings about the current procedures in the juvenile courts. Kent v. United States, 383 U.S. 54I, 555-56 (Ig66).

${ }^{100}$ See Rosenheim, The Child and His Day in Court, Child Welfare, Jan. 1966, p. 17.

${ }^{107}$ ILL. REV. STAT. ch. $37, \$ \$ 70$ T-08 (I965).

${ }^{108}$ Caz. Welfare \& INst'Ns Code $\$ \S 500-827$; N.Y. Family Court Act, N.Y. Sess. Laws 1962 , ch. 686, art. 7 .

${ }^{109}$ ILI. REv. STAT. ch. 37, $\$ 704-6$ (1965).

${ }^{110}$ IIL. REv. Stat. ch. 37, $\$$ Tor-20(I) (I965).
} 
reports, may be admitted and may be relied upon to the extent of its probative value, even though not competent for the purposes of the adjudicatory hearing. ${ }^{111}$

On the other hand, the substantive reach of state power under the Illinois Act has not been diminished. "Delinquency" has been narrowed to violations of law, ${ }^{112}$ but a new category of deviance-covering minors "otherwise in need of supervision"sponges up those adolescents operating within minimal standards of conduct (i.e., the criminal law) but below the maximal standards imposed on adolescents. A minor "otherwise in need of supervision" is one "who is beyond the control of his parents... [or] habitually truant from school."113 The statute goes on: a "neglected minor" is one "who is neglected as to proper or necessary support, education as required by law, or as to medical or other remedial care recognized under State law or other care necessary for his well-being, or who is abandoned . . . or . . . whose environment is injurious to his welfare or whose behavior is injurious to his own welfare or that of others." A14 A "dependent minor" is one "who is without a parent ... or ... who is without proper care because of the physical or mental disability of his parent" and so forth. ${ }^{115}$ All four categories of adolescents (or their parents, as the case may be) are within the jurisdiction of the Juvenile Court. They are subject to a wide variety of sanctions, such as probation, with varying degrees of "protective supervision" (e.g., parents may be ordered "to refrain from acts of omission that tend to make the home not a proper place for the minor"116), or the adolescent can be taken from his parents and put in the custody of a "suitable relative or other persons," "an agency for care or placement," "some licensed training school or industrial school."117 Guardianship (defined in the statute as "the duty and authority, subject to residual parental rights and responsibilities, to make important decisions in matters having a permanent effect on the life and development of the minor"118) may be given to a probation officer. ${ }^{119}$ However, only "delinquents" may be sent to the traditional juvenile custodial institutions. ${ }^{120}$

In view of the still extensive substantive regulation, one wonders what the Illinois Act has accomplished. The range of deviance has not been narrowed legislatively. As long as the four categories of adolescents are potentially within the jurisdiction of the juvenile court, the adolescents and their families are still subject to the regulatory authority of the police and intake staff. The police are still charged with the duty of investigating home conditions, family life, moral conduct, as well as crimes committed by juveniles. A small piece of the policeman's lever has been taken away: unless the adolescent has violated a law, he cannot be committed to a custodial insti-

\footnotetext{
${ }^{111}$ ILI. REv. STAT. ch. 37, \$705-x(I) (I965).

212 ILI. REV. STAT. ch. 37, $\$ 702-2$ (I965).

${ }^{113}$ ILl. REv. STAT. ch. $37, \$ 702-3$ (1965).

11* ILI. Rev. Stat. ch. $37, \$ 702-4$ (1965).

${ }^{115}$ ILL. REv. STAT. ch. 37, $\$ 702-5$ (1965).

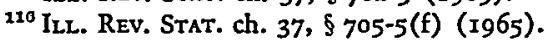

${ }^{217}$ ILL. REV. STAT. ch. 37, $\$ 705-7$ (I) (a), (c), (d) (1965).

${ }^{118}$ ILI. REv. STAT. ch. $37, \$ 70$ I-II (I965).

${ }^{110}$ ILI. REv. STAT. ch. 37, § 705-7 (I) (b) (I965).

${ }^{220}$ ILI. REv. STAT. ch. $37, \$ 705-7(\mathrm{I})$ (e), (f) (1965).
} 
tution. But the important fact is that so much else can be done to him and his family. The extensive informal regulation will probably continue to function pretty much as before; and, thus, the procedural reforms of the act may also lose a fair part of their importance. The vast majority of cases will still never get to court; many of the ones that do will not be contested.

The Illinois act has not broken with the basic dogmas of the juvenile justice system. Thus, it states, "The purpose of this Act is to secure for each minor ... such care and guidance ... as will serve the moral, emotional, mental, and physical welfare of the minor and the best interests of the community ... [and] to preserve and strengthen the minor's family ties whenever possible ...."121 Delinquency, even narrowly defined, is still merged in one unified administrative system with "minors otherwise in need of supervision" and victims of dependency and neglect, and all are subject to the coercive powers of law enforcement officials. Law enforcement power is still not confined to crime: it is still being invoked for treatment services.

What are the alternatives to approaches like the Illinois Act? Should the surgery be more radical? If distinctions are to be made between criminal conduct, on the one hand, and inadequate family functioning, on the other, then maybe the administrative systems ought to be separated also. Perhaps it is a mistake to have a unified juvenile court. Delinquency, with its attendant law enforcement regulation, could be taken out of the civil court system and returned to the criminal courts. This does not have to mean that adolescents would be subjected to the horrors depicted by the early spirits behind the juvenile justice reform movement sixty-five years ago. There still could be separate court rooms, detention facilities, probation staff, custodial-treatment institutions, and other substantive and procedural modifications. The critical question, however, is this: what would be the impact of such a separation on the lower-level administration? The Chicago police maintain that they now only investigate charges of dependency and neglect and refer developed cases to social agencies or the court without police regulation. We don't know the practices in other police departments, but if they also regard dependency and neglect as outside normal police functions, then separating administrative systems should not significantly affect police practices. The police would still be receiving a heavy volume of dependency and neglect complaints, and they would discover others in the course of their regular duties. ${ }^{122}$

The more troublesome dilemma 'concerns delinquency. Problems of pre-court regulation-investigation, detection, Community Adjustment-must be faced as long as we agree that adolescents who commit crimes should not go free. Even if

\footnotetext{
${ }^{122}$ ILI. REv. STAT. ch. 37,5 701-2 (1965).

122 Illinois has recently enacted an Abused Child Law, ILL. REv. STAT. ch. 23, 5204 I (1965), which provides service by the Department of Children and Family Services to receive and act upon complaints of a "battered child." What effect this act will have on current police practices is not known. We would guess that it will further encourage the police to make speedy referrals in neglect cases. The police, however, will still remain the principal initial receivers of complaints. The police are normally used for after-hours emergencies-e.g., accidents, mental health, as well as abused children.
} 
definitions of delinquency were narrowed to reflect only minimal standards of conduct-to encompass only would-be felonies (if committed by adults) plus petty theft, vandalism, sex offenses, assaults, and so forth-existing Community Adjustment practices might not be affected significantly. Community Adjustment, again according to the Chicago police, is currently not used for individuals "beyond the control of parents" or guilty of truancy and other noncriminal conduct; these cases, too, are referred to social agencies, school authorities, or simply not bothered with. In other words, the extensive police regulation that appears to raise significant privacy issues may already be reserved for those exhibiting criminal behavior, thus failing to meet the minimal standards of conduct applicable to adults as well as adolescents.

If this is true, then we are faced with the question of whether we really want the police to stop administering social services for adolescents in trouble. Do we want the police to return to prior methods of law enforcement? It is important to recognize that in the large urban centers, the problem is massive. In 1965 , the Chicago Youth Division handled 92,453 cases; of this total, 15,217 involved serious offenses (murder, rape, serious assault, burglary, and so forth); 14,49I were of a less serious nature (drinking, disorderly conduct, simple assaults, sex offenses, and crimes against property); 9,948 defendants were simply incorrigible, runaways, or in similar diffculty; 25,524 cases were curfew violations. ${ }^{123}$ At the present time, the police are the primary, if not the only agency, out in the field attempting to deal with violations by adolescents. Who is to take their place? Can we have social workers manning the city streets twenty-four hours a day?

It seems clear that in the immediate future at least some form of screening process will continue to be used for adolescents in trouble and that in most communities the principal screeners will continue to be the police. But police handling of juveniles can be improved. Chicago's Youth Division Manual tries to suppress improper criteria, such as race and demeanor, and more work has to be done in this area. Standards for the administrative handling of adolescents can be tightened. More rules for lower-level officials are badly needed. Police decisions should be made more visible, and their criteria should be made more uniform. Officers need guidance. At the present time, they are required to strike delicate balances, on the spot, between privacy interests and law enforcement demands, and they lack sufficiently definite rules and proper training. The police also need more support from other professional sources. Additional juvenile court judges can relieve the pressure for Community Adjustment and provide more court supervision of informal dispositions. Additional social workers can be made available for consultation and help in supervision. Pre-court regulation can be improved to mitigate the harshness of formal proceedings and at the same time protect the individual.

${ }^{133}$ Youth Division, Chicago Police Departaient, Data Sheet (ig65). 
IV

\section{Treatment, Privacy, and Public Policy}

When government enacts and administers programs dealing with people, it interferes with personal behavior; indeed, this is usually the intention of the program. The issues raised are simply the costs of the interferences as measured by the legislative purposes or, stated another way, whether the regulation of people's lives is reasonably justified in terms of sound legislative goals. For us at least, there is no other side to the issues concerning the older style of welfare or the overtly punitive features of modern welfare. We think it clear that governmentally imposed badges of poverty, midnight raids, coercively-imposed celibacy for AFDC mothers, as well as other repressive conditions of public assistance are impermissible. We would view in the same way nineteenth-century (and earlier) methods of handling adolescents in trouble that are still practiced and defended in certain parts of the country today.

For us, the more interesting and difficult issues of privacy arise in the humanitarian, progressive programs. This is ironic, but we have tried to show that changing conceptions of "need" have expanded the legitimate activity of government into the lives of its clientele. The juvenile justice movement may be viewed as the forerunner of modern humanitarian welfare. Government interferences under the humanitarian approach are extensive. They take subtle forms, and, most significantly, it is not at all clear that they are unwarranted. Solutions, in the form of redefinitions of public goals and the formulation of objective rules, are hampered by conceptual dilemmas and the lack of scientific knowledge. We still know very little about the causes and cures of deviant behavior, alienation, chronic economic dependency, and the other characteristics of the dependent poor. Techniques of changing behavior, whether monetary incentives, education, blandishments, or force, conflict with deeply held values of freedom, individualism, and dignity. In the face of practically all proposals for meaningful reform loom the intractable problems of administration: the sheer volume of delinquency and dependency, the lack of public support for welfare and rehabilitation, and the lack of professional and institutional resources.

The dilemmas imbedded in the administration of juvenile justice pose the privacy issues for welfare. It is easy to deplore the ineptness of police practices, the lack of substantive and procedural standards in the juvenile courts, and the shoddy treatment given to adolescents. It is less easy, we believe, to come up with solutions beyond strengthening and improving the administration of juvenile justice now being practiced in the more enlightened jurisdictions. We can press for tighter standards, for more objective rules for administrative officials, and for more and better trained personnel. Admittedly, these are modest goals, but they may be realistic. And at least at the present time, they seem better than returning to prior methods of law enforcement. 
Much too can be done with public assistance. Dependent poor (unlike the poor who manage somehow without public help) are regarded as a class in need of redirection. Methods of redirection vary over time-being in one age repressive, in another idealistic, and in a third professional, operating through enlightened persuasion and counseling techniques. Remaking personal habits and reshaping personalities are constant themes from the earliest days of public assistance to the asserted professionalism of today. ${ }^{124}$ But "rescue," however undertaken, carries with it seeds of harm and the ever-present risk of turning a Good Samaritan into a "pursuing Fury."125

One method of reducing the bind of the strings attached to assistance is to reduce the group of dependent poor through the expansion of employment opportunities. But this method has its limits. Even with full employment, there will always be the "unemployables," just as we will always have adolescents in trouble. We can also increase the dependents who receive assistance relatively free of conditions. The aged, the survivors or dependents of insured wage earners, and the unemployed (to a lesser degree) receive benefits under fixed formulae with few if any strings attached. Additional income assistance devices can rest on more objectively determined standards of eligibility. Discussions of guaranteed annual income measures, expansion of social insurance, and family allowances point in this direction. Even though (as already noted) average-benefit or pension-type measures will not wholly eliminate the need test, ${ }^{126}$ more specific statutory standards and better methods of administration should contract the arena of discretion and the worrisome influence of official authority.

The expansion of entitlement varieties of income maintenance neither allays the pervasive concern to avoid subsidizing the indolent nor does it necessarily promote the rehabilitative goals now embodied in modern welfare. Work incentive still

${ }_{124}$ Even measures now regarded as entirely punitive were not necessarily so regarded when instituted. The Royal Commission for Inquiring into the Administration and Practical Operation of the Poor Laws (1832-1834) saw, in its recommended measures of poor law reform, rehabilitative benefits to the poor flowing from the assumed impact of law on personal morals, work incentives, and the regulation of institutional administration. See, e.g., excerpts cited in DE ScHwernitz, op. cit. supra note 2, at 122-27. Likewise, in the United States, the abolition of outdoor relief and creation of almshouses were hailed not only as tax-saving devices but valuable measures for intellectual and moral training of children. See Report to the New York Legislature of I824 [Yates Report], reprinted in Sophonisba P. Breckinridge, Public Welfare Administration 39-54 (I938).

${ }^{195}$ Charles Dickens, Our Mutual Friend 506 (Oxford, 1952).

${ }^{120}$ It may be noted that the number of OASDI beneficiaries concurrently in receipt of old age assistance has been rising. This trend is attributable to various factors-OASDI benefit levels, rising standards of assistance for the aged, and also unpredictable and substantial expenses (particularly costs of medical care). See Eppley, Concurrent Receipt of Public Assistance and Old-Age, Survivors, and Disability Insurance by Persons Aged 65 and Over, Early 1963, Welfare in Review, March 1964, p. 18. Note also that Congress, in the 1965 amendments to the Social Security Act, not only added title I8 for hospital and medical insurance (79 Stat. 291, 42 U.S.C.A. \$\$ $1395-1395 l l$ (Supp. I965)) but also title I9 (79 Stat. 343, 42 U.S.C.A. $\$ \$ 1396-1396$ d (Supp. I965)), an assistance program based on a means test for the medically indigent, which may well become the more significant medical care program. See generally Glasser, Extension of Public Welfare Medical Care: Issues of Social Policy, Social Work, Oct. I965, p. 3; Winston, Implications of the 1965 Amendments to the Social Security Act, Social Work, Oct. I965, p. 10. 
remains a proper consideration in the formulation of income maintenance programs. The level of annual income is fixed with regard to wage scales as well as assumed needs. The level has to balance deterrence against increased proportions of dependents on the public's bounty. Generalized criteria and tax-like methods of administration will tend to mitigate the privacy issues; but, depending on the level to be fixed, they will also create hardships in individual cases.

The intertwining of income and service accounts for a major portion of official intrusion. The phenomenon is old; only the label of "service" is new. As with delinquency, the service aspects present the more intractable problems. The suggestion has been made repeatedly that the broader services be dealt with wholly outside the income-maintenance structure. Rehabilitative goals transcend income lines. ${ }^{127}$ The need for service is not limited to the dependent poor, even though certain ills may be special burdens of poverty. Above the poverty line, we are content to let individual choice prevail. Literacy training, marital counseling, daycare centers, as well as other services, are available to those who wish them. The expanded services for the dependent poor may be voluntary; but, as we have seen, the connection between assistance and service opens the door to subtle forms of official coercion. More objective administration of eligibility will not wholly eliminate the ability of officials to impose their notions of therapy upon recipients; this is especially true as long as special needs are recognized for individual cases. Fluid classifications and the ambitiousness of social aims account for the increase in authority in the more progressive programs.

Again we ask a question similar to that asked regarding the administration of juvenile justice: Should we separate out all service components from income maintenance? It is true that all social classes contain some parents and children who are foolish and in result an evil to themselves and to society. But we think it superficial to argue that because government does not attempt to redirect the rich, it should never attempt to redirect the poor. Better arguments must be made. Freedom might be maximized but at what social cost? The vulnerable and unprotected may fail to act or they may be prevented from acting by the oppressive social forces in the slum environment. Yet official attempts at redirection also have their costs, as we have seen. Whatever policy decisions are made in welfare, we are imposing value choices on the dependent poor and our own notions of what is good for them.

\footnotetext{
${ }^{287} \mathrm{Kahn}$, Social Services in Relation to Income Security: Introductory Notes, 39 Soc. SERv. REV. 381 ( 1965$)$. On the probability of separating services from income in public assistance, a goal he espouses, Kahn remarks:

". . . the call for simplification of the means test and some system of flat-grant budgeting in the assistances would lead the two programs [public assistance and social insurance] even closer to cach other. It may be that reasons of efficiency and economy will take us where public re-evaluation of recipients is not yet prepared to go." Id. at 384 . (Emphasis added.)
} 